not missed a single day of school since starting danazol. He has maintained a normal growth velocity and has shown no androgenic or other side effects.

\section{Discussion}

Hereditary angio-oedema is characterised by oedema of the face, airways, extremities, and gut wall. The consequences may be life threatening, particularly if it affects the larynx and trachea. ${ }^{3-4}$

It is inherited as an autosomal dominant, the essential lesion being a qualitative or quantitative deficiency of $\mathrm{Cl}$ esterase inhibitor. Under normal circumstances $\mathrm{Cl}$ inhibitor exerts a halting influence on the $\mathrm{Cl}$ component and stabilises the complement system. ${ }^{5}$ Many drugs have been tried in the treatment of this condition. Inhibitors of serine proteases-for example aminocaproic acid-were the first to be tried, followed by tranexamic acid. While these agents are useful in acute attacks, danazol has been found effective in prevention. It has been shown that danazol induces $\mathrm{Cl}$ esterase inhibitor activity and thus prevents attacks. ${ }^{6}$ We feel that the use of danazol is justified. Arguments against its use in children are mainly based on fears that it suppresses growth and gonadal function. These theoretical complications may be acceptable if there are frequent hospital admissions and the child and the parents are in constant fear of severe airways obstruction. In our patient a significant reduction in symptoms occurred on a dosage of danazol that did not cause any rise in serum testosterone level. After discussion with the boy and his parents we felt that it was correct to continue treatment, but his endocrine function is being closely monitored.

We thank the Department of Biochemistry, Northampton General Hospital for their help and Mrs M Boulby for secretarial assistance.

\section{References}

1 Potts G O. Pharmacology of danazol. J Int Med Res 1977; 5: Supplement 3, 1-14.

2 Smith C S, Harris F. Preliminary experience with danazol in children with precocious puberty. J Int Med Res 1977; 5: Supplement 3, 109-13.

3 Anonymous. Treatment of hereditary angio-oedema. Lancet 1979; i: 417.

4 Donaldson V H, Rosen F S. Hereditary angioneurotic edema : a clinical survey. Pediatrics 1966; 37: 1017-27.

5 Donaldson V H, Evan R R. A biochemical abnormality in hereditary angioneurotic edema: absence of serum inhibitor of $\mathrm{Cl}$ esterase. Am J Med $1963 ; 35$ : 37-44.

- Gelfand J A, Schein R J, Alling D W, Frank M M. Treatment of hereditary angioedema with danazol: reversal of clinical and biochemical abnormalities. N Engl J Med 1976; 295 : 1444-8.

Correspondence to Dr C Rajagopal, Department of Paediatrics, Duchess of Kent Military Hospital, Catterick, North Yorkshire.

Received 5 February 1980.

\title{
Value of the gastric aspirate shake test
}

\author{
M L SMITH, D CURNOCK, AND F FORSHAW \\ Neonatal Unit, City Hospital, Derby
}

\begin{abstract}
SUMMARY The results and predictive value of the gastric aspirate shake test are reviewed in 432 preterm babies admitted to a neonatal unit during a 3-year period. It is concluded that the degree of prematurity is a better indicator of the chance of developing idiopathic respiratory distress syndrome than the test itself.
\end{abstract}

Respiratory distress syndrome (RDS) still continues to be a common neonatal problem and is all too frequently a cause of neonatal death. The deficiency of surfactant can be predicted antenatally by measuring the lecithin-sphingomyelin ratio in amniotic fluid. ${ }^{1}$ A simple method (the shake test), also carried out on amniotic fluid, was described by Clements et al. ${ }^{2}$ This test has been used by others ${ }^{3-6}$ on gastric aspirate and the results showed that a negative result correlated well with the development of RDS. It has been suggested that the results of a shake test might help to decide whether a preterm baby should be transferred to a regional centre ${ }^{3}$ it also differentiates RDS from other causes of neonatal respiratory problems. ${ }^{\text {? }}$

\section{Patients and methods}

Since 1976 each preterm baby admitted to the 
Table 1 Incidence of respiratory distress syndrome in 432 infants

\begin{tabular}{llll}
\hline $\begin{array}{l}\text { Gestation } \\
\text { (weeks) }\end{array}$ & \multicolumn{2}{l}{ Infants } & $\begin{array}{l}\text { Incidence (\%) } \\
\text { of } R D S\end{array}$ \\
\cline { 2 - 4 } & With RDS & Without $R D S$ & \\
\hline $28-29$ & 21 & 14 & 60 \\
$30-31$ & 14 & 30 & 32 \\
$32-33$ & 18 & 53 & 25 \\
$34-36$ & 27 & 255 & 9.5 \\
\hline
\end{tabular}

Table 2 Results of shake test in 250 infants and incidence of respiratory distress syndrome

\begin{tabular}{llll}
\hline & \multicolumn{3}{l}{ Respiratory } \\
\cline { 2 - 4 } & No wistress syndrome \\
\hline Test not performed & 33 & No without & $\%$ with \\
Results of test & & 149 & 18 \\
Negative & 28 & 54 & 34 \\
$1+$ & 13 & 31 & 29 \\
$2+$ & 4 & 40 & 9 \\
$3+$ & 2 & 56 & 3.5 \\
$4+$ & 0 & 22 & 0 \\
\hline
\end{tabular}

neonatal unit at Derby City Hospital has had a shake test done, or one has been attempted, by aspirating the baby's stomach soon after birth. A shake test, as described by Clements et al., ${ }^{2}$ has then been performed without dilution by the nursing staff. We have studied the notes of all the preterm babies admitted to the unit between January 1976 and 31 December 1978, retrospectively. The absence or presence of RDS was reassessed in each using the criteria of Baden et al. ${ }^{8}$

\section{Results}

During the period 432 preterm babies were admitted to the unit. The incidence of RDS fell with increasing maturity (Table 1) from $60 \%$ at 28-29 weeks' gestation to $9.5 \%$ at $34-36$ weeks, an overall incidence of $18.5 \%$. A total of $250(58 \%)$ babies had shake tests performed of which 82 were negative, but only $28(34 \%)$ of these babies developed RDS as did a similar proportion, $14(32 \%)$, with a shake test graded plus 1 . The more positive the shake test the less likely was the chance of RDS (Table 2).

\section{Discussion}

The figures may be criticised in that the incidence of RDS at 34-36 weeks is inaccurate as some babies of 36 weeks' gestation would not be admitted to the unit. Secondly, the poor correlation between RDS and a negative shake test might be due to the fact that the test was carried out incorrectly or was misread.
However, the results are similar to those of Speer et al. ${ }^{4}$ who showed a $75 \%$ false-negative result, our figure being $66 \%$. Others report better correlations between results of the shake test and presence of RDS but Evans, ${ }^{3}$ and Tanswell and Smith, ${ }^{5}$ still had a fairly large false-negative rate (40 and $31 \%$ respectively) which makes the test inaccurate for the prediction of RDS.

Our results suggest that a large proportion of infants with negative tests do not develop RDS and its value in determining the need for transferring preterm babies to regional centres, as has been suggested, ${ }^{3}$ is limited, the degree of prematurity correlating better with the development of RDS. Our figures for RDS are similar to those of Roberton. ${ }^{9}$ We feel that the test is worth performing as an aid to management and diagnosis of respiratory problems, the chances of RDS with a very positive test being unlikely. However the frequency of false-negative tests means that it cannot be used reliably to distinguish between RDS and group B streptococcal pneumonia. ${ }^{?}$

\section{References}

1 Gluck L, Kulovitch M V, Borer R C J, Jr, Brenner P H, Anderson G G, Spellacy W N. Diagnosis of the respiratory distress syndrome by amniocentesis. Am J Obstet Gynecol $1971 ; 109$ : 440-5.

2 Clements J A, Platzker A C G, Tierney D F. Assessment of the risk of the respiratory distress syndrome by a rapid test for surfactant in amniotic fluid. N Engl J Med 1972; 286: 1077-81.

3 Evans J J. Prediction of respiratory distress syndrome by shake test on newborn gastric aspirate. $N$ Engl $J$ Med 1975; 292: 1113-5.

4 Speer M G, Corbet A J S, Flax P, Rudolph A J. The foam stability test on gastric aspirate in the prediction of respiratory distress syndrome. Acta Paediatr Scand 1977; 66: 485-7.

5 Tanswell A K, Smith B T. Letter: The gastric aspirate shake test. $N$ Engl J Med 1977; $297: 1471$.

6 Tanswell A K, Sherwin E, Smith B T. Single step gastric aspirate shake test. Arch Dis Child 1977; 52: 541-4.

7 Lewins M J. Letter: The gastric aspirate shake test and group B streptococcal disease. $N$ Engl J Med 1978; 298: 1200.

8 Baden M, Bauer C R, Colle E, Klein G, Taeusch H W, Stern L. A controlled trial of hydrocortisone therapy in infants with respiratory distress syndrome. Pediatrics 1972; 50: 526-34.

9 Roberton N R C. Respiratory disease in early life. In: Stretton T B, ed. Recent advances in respiratory medicine. Vol. 1. Edinburgh: Churchill Livingstone, 1976: 211-79.

Correspondence to Dr M L Smith, Bradford Children's Hospital, St Mary's Road, Bradford, Yorks BD8 7QF.

Received 23 April 1980 